This is a self-archived version of an original article. This version may differ from the original in pagination and typographic details.

Author(s): Horsti, Karina

Title: Refugee testimonies enacted : voice and solidarity in media art installations

Year: 2019

Version: Accepted version (Final draft)

Copyright: (c) 2018 Routledge

Rights: In Copyright

Rights url: http://rightsstatements.org/page/lnC/1.0/?language=en

Please cite the original version:

Horsti, K. (2019). Refugee testimonies enacted : voice and solidarity in media art installations. Popular Communication, 17(2), 125-139. https://doi.org/10.1080/15405702.2018.1535656 
Refugee testimonies enacted: Voice and solidarity in media art installations Author: Karina Horsti

Academy of Finland Fellow

Department of Social Sciences and Philosophy

University of Jyväskylä, Finland

Karina.horsti@jyu.fi

Acknowledgments: The author would like to thank the anonymous referee, the special issue editors Maria Rovisco and Jonathan Ong as well as Klaus Neumann who all offered helpful comments on the first version of this paper. The analysis of Candice Breitz's artwork and the protest at the National Gallery of Victoria are based on the thinking and writing with Klaus Neumann and the author is grateful for his inspiring contribution. In addition, she thanks curators Maria Andersin and Simon Maidment for insightful conversations. 
Abstract:

This paper examines how two media art installations in which celebrity actors enact refugee storytelling create awareness to the complexities of representation and solidarity with refugees. The celebrity actor produces familiarity, or "audibility", for contents of the stories. Yet, at the same time the familiarity of the actor alerts the visitor to the politics of listening. The artworks therefore manage to produce the potential for ethical listening, which requires interrogation into the privileges of the listener. The artworks produce a kind of sociality different from that of typical celebrity advocacy. Instead of being at the centre of attention, the actors' presence draws critical attention to the politics of listening.

Keywords: Memory, refugees, contemporary art, listening, celebrity 


\section{Introduction}

Stories of refugees and asylum seekers have proliferated in recent years in the European cultural field, particularly during and after the European "refugee reception crisis" of 2015. Artists, theatre directors, authors and filmmakers have been at the forefront with journalists and activists to document one of the most catastrophic situations in recent years. This paper explores how listening to the stories of refugees in and through contemporary art could produce solidarity between those who have to flee and those who do not. Attention to the critical potential of the arts is particularly important in present-day Europe, where political and popular visions of human rights and seeking refuge are becoming more and more narrow.

There is a long tradition in Europe of seeing the arts "as the source of an 'ethical vision' and a repository of human values" (Belfiore and Bennett 2008, p. 10), and the creative attention paid to the conditions of refugees in contemporary art can be understood as a continuation of this. The conceptualization of the arts as a socially impactful practice requires artists and museums to provide communicative spaces and cultivate sociality across differences.

Documentary arts, which work with the material of real-life events, are a broader recent trend in the creative arena. However, documentary art has long roots, one notable phase being the Great Depression of the 1930s, when a group of artists in the UK began to document people's suffering and struggles through realistic aesthetics as 
a countermovement to abstraction and surrealism. More recently, after the attacks of September 11, 2001, several novelists turned from fiction to essays; in the words of VS Naipaul, they believed that "fiction is no longer adequate to make sense of the world" (Webb 2009, p. 67). The documentary approach in the arts, therefore, could be seen as a response to events that disturb the social order and artists' sense of ontological security. Artists who engage with real-life events feel a responsibility and an obligation to search for the "ethical vision".

Storytelling has been one of the main strategies for artists working with refugee experiences. While the notion of the "subaltern voice" has been critically interrogated since Gayatri Chakravorty Spivak's (1988) seminal essay “Can the Subaltern Speak?" as well as re-thought in the context of recent practices of self-narration in the digital era, the theorization of voice - the capability to speak and to be heard - remains an unfinished matter (in media and cultural studies, see e.g. Husband, 1996; Sreberny, 2006; Couldry, 2010; Dreher, 2009; 2012; Ong, 2014; Rovisco, 2015; Musarò, 2017). The notion of "refugee voice" needs careful reflection: It assumes that there is one voice rather than many, and the idea of "giving" a voice to refugees (through art, for example) involves a power dynamic between the party who has resources to "give" and the party who accepts the opportunity to speak in the context provided them. Moreover, the public to whom the story is narrated is often imagined as the White middle class (Ong 2014, p. 189).

Furthermore, scholars of performance such as Catherine Wake and Saidiya Hartman have brought attention to the ethics of repeating narratives of violence, suffering and pain. In Saidiya Hartman's terms, the problem is how to replay "scenes of subjection" 
without creating more of the same. In such scenes, the person who repeats their own story or the fictionalized story of an abstracted refugee may again be objectified and defined predominantly in terms of suffering. (Wake, 2009.)

Within media studies, Tanja Dreher $(2009 ; 2012)$ has addressed the hierarchies of voice and audibility by focusing on the position and practice of the one who listens. Listening requires opening oneself up to the possibility of change and vulnerability. Dreher (2009) ${ }^{1}$ has developed a model of ethical listening across difference at the intersection of feminist and critical race studies that requires horizontal engagement with the one who is listened to. In this approach, the ethical imperative of listening is to be attentive to one's own privileges and complicities. Therefore, ethical listening is not an attempt to cognitively understand and explain the Other or that which is different, but to understand unequal relationships and power dynamics. Instead of explanation, listening means presence and openness to recognizing the incompleteness and unsettledness that emerges in encounters across differences.

This ethical approach to listening is helpful in thinking about solidarity in the context of the relationship between refugees and Western publics. This relationship is complex and needs to be defined in relation to such humanitarianism that does not carry reciprocity but is instead based on a hierarchical relationship between one party who has the resources to help and the other who receives generosity. Rights-based solidarity, on the contrary, is an emotionally and morally motivated practice that strives for mutual support (Ticktin, 2011; Fassin, 2012, pp. 2-4; Horsti, 2013; Chouliaraki, 2013, pp. 11-13). Social philosophy shows how solidarity is often

1 Tanja Dreher draws on the feminist scholarship of Susan Bickford (1996) and Krista Radcliffe (2005). 
produced through shared experience and the feeling of belonging together, such as forms of sociality based on shared civic life or struggles to overcome injustice (for an overview, see Laitinen, 2013). However, solidarity can also refer to a universal ethical responsiveness to humanity (Rorty, 1989; Scholtz, 2008; Laitinen \& Pessi, 2015) that goes beyond "we-thinking" - thinking that produces opposition between "us" and "them". In this sense, solidarity can also refer to a basic ethical concern for others: a moral, global or human solidarity.

Through an examination of two media art installations, this paper discusses the potentiality of contemporary art to produce solidarity between the (presumed Western) public and refugees through storytelling and listening. I have examined the two artworks, their situated aesthetics and the debates surrounding them, and have analysed the scripts of the refugee narratives used in the artworks as well as additional materials provided by the artists on their websites and social media. I have also examined how the artists have described their work in public. Contemporary art as a context for the study of mediated storytelling and listening brings forward the role of the artist (as the one who listens and re-tells) and the situatedness of the telling in a more apparent way than most other genres of media and popular communication.

In this paper, I draw attention to the ways multiple voices are presented and connected in the artworks as well as to how the pieces position the listener. The stories are first listened to by the artists, then by the actors who enact the stories in the installations, then by museum curators, and finally, by the visitors. Moreover, I study the multidirectional potential of producing solidarity through art by considering the references and connections to histories, identity positions, cultural signs and 
experiences that might produce mutual understanding and invite reciprocity. I also discuss the role of celebrity actors in the two pieces and examine the ways they shape the politics of listening and voice and position the refugee story in the cultural sphere. Both installations use celebrity actors who enact the storytelling of refugees, and in doing so, the installations appear not only in the sphere of contemporary "high" art but also in the sphere of popular culture. The actors, familiar to museum visitors from television and film, potentially appeal to a wider public than contemporary art institutions tend to reach.

Research on celebrity advocacy in the humanitarian field has been critical of how oftentimes, the emotions of the celebrities themselves become the centre of attention and point of identification. Although celebrities attempt to bring attention to humanitarian causes and transform or "authenticate" distant suffering for domestic settings, celebrities, their glamour and their feelings are arguably substituted for the voice of the sufferer. Thus, while celebrities "give their popular voice" to the refugees, they often end up becoming the centre of attention. (Goodman \& Barnes, 2011; Chouliaraki, 2012; Driessens, Joye, \& Biltereyst, 2012.) In contrast to the role of celebrities in humanitarian advocacy, I argue in this paper that the celebrities in the artworks I examine perform a different social relationship and offer the potential for a different kind of sociality. While the "glamour" of the popular actors attracts the attention of the public, the media art installations invite the visitor to reflect on the politics and ethics of listening and telling. The installations invite the visitor to consider whose suffering affects the viewer and whose storytelling receives attention. The pieces explicitly interrogate their metarepresentation by creating awareness of the complexities of representation and of solidarity with refugees. 
First, I examine Finnish artist Timo Wright's audio installation The Long Journey Home (2012/2017), which combines eight stories told to the artist by present-day refugees, internally displaced people from Finnish Karelia (in 1939-1945) and Finns who had been evacuated to Sweden as so-called "war children" during WWII. The stories amalgamate into one in the voice of a familiar Finnish actor, Vesa Vierikko, who performs the different experiences without mentioning any names or places. Wright first exhibited the sound installation in 2013 in Galleria Rajatila, a Finnish art gallery, but I saw the piece in a Finnish history museum exhibition (Open your heart, Lotta Museum, 2017) about humanitarian aid in Finland in 1941-1952, during and after the war with the Soviet Union.

The second work I examine is a multichannel installation Wilson Must Go/Love Story (2017) by South African artist Candice Breitz, which I experienced at the National Gallery of Victoria in Melbourne, Australia. It was first shown at the Kunstmuseum Stuttgart, Germany, in 2016 and subsequently has been shown around the world in museums such as the Arken Museum of Modern Art in Denmark and the Museum of Fine Arts, Boston. The installation is divided into two spaces. In the first space, Hollywood actors Alec Baldwin and Julianne Moore re-enact stories told by presentday refugees. The script is cut from transcripts of six refugee testimonies in a fastpaced montage. In the second space, the visitor is invited to sit across from each of the six refugees, who simultaneously perform their testimony on six television screens equipped with headphones. At the National Gallery of Victoria, Breitz renamed her work as Wilson Must Go as a protest against the Gallery's contract with Wilson 
Security, which has been accused of human right violations in Australia's off-shore detention centres.

\title{
The Long Journey Home
}

\author{
"The day I left was an ordinary day of the week. We lived in (muted) and \\ suddenly we heard the bombings. The war was starting. The neighbours got \\ together to discuss what was going on, and my mother was confused. My \\ mother said 'now you need to leave' because the buildings across the street \\ were bombed. We took only our shoes." The Long Journey Home, 2017.
}

The familiar voice of Finnish actor Vesa Vierikko recounts this story of fleeing a home. He articulates the tragic experience clearly and with concentration. I hold the installation's old-fashioned telephone receiver to my ear and recall Vierikko's role as one of the soldiers in the well-known film Talvisota/The Winter War (1989). It is comforting to listen to this voice, which is so recognizable - almost like a family member speaking to me. I maintain my concentration as the story changes: without interruption, another person's experience of being forced to flee begins. I don't know where or when these events took place, but all the stories recall the moment a person had to leave his or her home. The repetition of the different, yet similar, memories of leaving amalgamate into one story; it is both one story and multiple stories at the same time. I can tell that the names of the places that had to be abandoned were included in the original script but omitted from the enacted version. Wright has not deleted the whole sentence, only the name of the place. Even the prepositions "in" 
and "from" (indicated by the suffixes -ssa, -sta in Finnish) are still there, which serves to draw the listener's attention to the absence of the place-names.

Through the similarity of the testimonies, the installation potentially produces solidarity among museum visitors toward present-day refugees - but only in cases where the visitor already identifies with Karelian evacuees and Finnish war children. However, most visitors, like myself, have not themselves lived through evacuations and war. The installation assumes that Finnish museum visitors are connected to these experiences through "prosthetic memory" (Landsberg, 2004): memory of an event that has not been lived through, but has been experienced only through mediation, for example in literature or film. The mediation can still produce a deeply felt experience, which then creates a personal and intimate "memory". The installation implicitly addresses visitors that identify as Finnish (or Karelian) and whispers the possibility that fleeing could have happened to you, too, if times were different, or that the story could be your grandmother's.

The installation presumes that the visitor "knows" the stories of the Finnish refugees and through them may be able to cultivate an ability to listen to and produce solidarity with present-day refugees. In doing so, the work produces a multidirectional potential to understand past and present experiences of war. Historian Michael Rothberg (2009) suggests that "we consider memory as multidirectional: as subject to ongoing negotiation, cross-referencing and borrowing: as productive and not private." The interaction of different histories in Wright's installation illustrates what Rothberg terms "multidirectional memory", that is, the "productive and intercultural dynamic" of memories (Rothberg, 2009, p. 3). The amalgamation of memories that takes place 
through the erasure of details and narration by a familiar and popular voice is productive. However, rather than producing a new multidirectional memory or a new vision of the past and present, I argue that the installation produces the potential to recognize the multidirectionality of memory. Wright's installation is not a storehouse from which memories are consumed: rather, memory "needs to be invoked, conjured, made" (Neumann, 2000, p. 8). The installation makes certain presumptions for the making of memory and solidarity that are rather unproblematized and nation-centred. The visitor is presumed to identify with Karelian evacuees and Finnish war children, which are underlined as being "Finnish experiences", and only though this premise is the visitor able to hear the experience of the present-day refugee. The situational setting of the installation emphasizes this reading.

The situational aesthetics (Papastergiadis, 2010) - the place and space of the work are as important as the work itself in the practice of conjuring memory and making something out of the multidirectional potential of the installation. The Long Journey Home originates from 2012, and was a political statement in response to the Finnish parliamentary elections of 2011, when anti-immigrant candidates obtained seats in the Finnish parliament and racist speech in online spaces had become a widely discussed issue. Alarmed by the rising anti-immigration movement, the artist felt obliged to create a position from which a gallery visitor could feel solidarity with present-day refugees through temporal similarities. (Wright, 2018.)

I experienced the installation at a different time and in a different setting, however. As I listened to the audio installation The Long Journey Home in the Lotta Museum in Tuusula, Finland, my gaze wondered around the surrounding exhibition. This was not 
a contemporary art museum, but rather a small rural museum presenting a specific narrative of the wars Finland fought with the Soviet Union. Lotta Svärd, the focus of the museum, was a Finnish auxiliary organization for women that was established in 1918 during the Finnish Civil War. Lottas, as the women of the organization were called, supported the conservative White Guard in the Civil War. During the Second World War, when Finland fought the Soviet Union, the Lotta Svärd organization mobilized women to replace the men who had been conscripted into the army. Lottas served in hospitals, at air raid warning posts, and in other auxiliary tasks in close cooperation with the army. Lotta Svärd also carried out voluntary social and humanitarian work. However, after the war, the Soviet Union demanded that Lotta Svärd and all the other paramilitary organizations be banned as "fascist" organizations. The funds of Lotta Svärd were transferred to a new humanitarian organization called the Finnish Women's Aid Foundation, which was to continue the humanitarian and social work of the Lottas. Only after the fall of the Soviet Union in 1990-1991 were the former Lottas able to make their history and memory public, and the museum was opened in 1996. Within the permanent exhibition documenting the history of Lotta Svärd, a special exhibition about the organization's humanitarian and social work, titled Spaces of love - Open your heart!, opened in 2017. This was the context in which Timo Wright's audio installation appeared, among historical photographs, documents, objects and audio clips recounting the humanitarian work carried out by many civic organizations in 1941-1952 under the broader umbrella organization Finnish Relief.

The Spaces of love exhibition had two sections: the first recalled memories of the journeys of the 400000 people evacuated from the ceded territories in Eastern 
Finland. Because the new border with Russia was drawn further west, the Finnish population in the ceded regions had to leave their homes and livelihoods and relocate elsewhere in war-torn Finland during and after the wars with the Soviet Union in 1939-1945. The other section of the exhibition - where Timo Wright's work was located - documented and honoured the member organizations of Finnish Relief. The organizations' aid was directed to orphans, widows, those disabled during the war and to what the exhibition refers to as siirtoväki - internally displaced populations.

Timo Wright's sound installation was surrounded by a spectacle of Finnish solidarity in the past. The photographs in the exhibition depicted equitable and unconflicted caregiving, and the factual explanations gave the impression that humanitarian support from the international community and the Finnish public was well organized and practical. Social inequalities were nowhere to be seen. The exhibition presented a harmonious and morally stable past. A Finnish visitor could feel proud and take the position of a moral agent: this is a nation that resettled more than 400000 people this was the message the exhibition conveyed.

The exhibition was unveiled soon after 2015, the year in which the number of asylum seekers in Finland rose almost tenfold compared to the previous year, to 32000 . The country had become divided between those who wanted to offer assistance to asylum seekers and those who responded with fear and even hate, attacking the people seeking protection. The juxtaposition of Wright's installation, which also pointed to the present, with a spectacle of the seemingly harmonious solidarity of the past produced an uncomfortable question: How did Finland manage to relocate 400000 
people into the country in the war-torn past when 32000 asylum seekers were now considered a crisis dividing the nation?

The spatial arrangement of the artwork encouraged the visitor to listen to the narratives and look at present-day refugee conditions from the perspective of the war generation. The work is premised on the idea that memories of events can be evoked by other events: the multidirectionality of memory (Rothberg, 2009). A collection of different narratives of history brought together in one space may surprise the visitor and prompt him or her to consider the present and the past from new perspectives. The arrangement creates an incentive to carry on the legacy and sense of responsibility that the exhibition seems to suggest is essential to Finnish citizenship. Therefore, in addition to the installation's invitation to listen to the stories of refugees, the positioning of the installation invites the visitor to listen to past generations of Finnish humanitarians.

The museum accomplishes this, however, by sanitizing and revising the history of post-war Finland, failing to listen to the unsettling, controversial, and uncomfortable voices of the past. While the past is evoked as a potential reference point for solidarity, the sanitizing of the past nevertheless risks to distance it. The narrative of resettling over 400000 people, 12 percent of the population at the time, is told as one of responsibility and solidarity - as a response to the call for "elävä kansallinen yhteistunto", "vibrant national solidarity", that president Kyösti Kallio made in his 14 March 1940 speech after the Winter War peace treaty was signed. However, as many scholars have argued, the resettlement of Karelian evacuees was not unproblematic (e.g. Sallinen-Gimpl, 1994; Raninen-Siiskonen, 1999). The locals across Finland were 
not always willing to assist the Karelians and often treated the newcomers with suspicion. There was also resentment over the fact that many Finnish landowners had to sell their land to the state for a nominal fee as part of the resettlement project.

In addition to temporal solidarity, the installation also attempts to produce spatial solidarity by underlining how memories travel with people (Erll, 2011). It therefore complicates the idea of territorially bound national memory and treats refugees as subjects in national history-making: Finnish history can be regarded as cumulative history (Neumann, 2016), as a hybrid and multi-voiced collection of the memories people carry with them.

Interestingly, the museum did not explicitly direct the Finnish visitor's attention to the multidirectional potential of the artwork or to its placement in the exhibition about the journey of the displaced Karelian population and the Finnish relief efforts. However, the page describing the exhibition on the museum's English-language website did draw visitor's attention in this direction by adding a reference to the so-called "refugee crisis" of the present. To underline the connection, where the Finnish Ministry of the Interior uses the term "asylum seekers", the museum website used the term "refugees": "This year, the Ministry of the Interior estimates that between 25000 and 30000 refugees will arrive in Finland, and a majority of them may stay in Finland permanently as immigrants. Time will tell whether we can handle it. Will there be enough love in Finland in 2017?"

The lack of an explicit connection drawn for Finnish visitors between past and present forced mobilities was a conscious decision. Curator Maria Andersin (2017) told me 
that the museum did not want to draw an explicit parallel between Karelian displaced persons and present-day refugees. There was a risk that such a historical parallel could be uncomfortable for the museum's core group of visitors. Some Karelian evacuees do not want to be referred to as "refugees", as the term may imply foreignness and bring into question whether they belong in Finland. Others, however, are active in the present-day Refugees Welcome movement precisely because they feel a connection to the experience of refugees arriving in Finland.

However, by putting these two mobilities into dialogue with each other, the museum is not only drawing from the past to make sense of the present. By making this connection, the museum is also seeking new audiences and new relevance for the past that it archives and exhibits. As Andersin (2017) points out, few members of the core museum audience - the former Lottas - are alive anymore, and the war children who were sent to Sweden as unaccompanied minors are also getting old. The museum is concerned with the question of how the experiences of the Lottas can remain relevant for future generations. Present-day refugee issues offer another kind of audience and topicality to the Lotta Museum.

\section{Love Story}

“Okay, I'm ready. So, her name is Julie? Start? Okay. Hi Julie! I'm Sarah and first, I want to thank you for doing this for us. People think about refugees in bad and horrible ways. They think we came here to steal their country, money, jobs and even their homes. We didn't come here to have another war. We just came to have a good future. My dream is to be a doctor and to swim in the national team. In Syria I can't do this. The message I want to give to the world 
is that we refugees are human, like every girl or guy in Germany." Sarah Ezzat Mardini, 18 October 2015, in Love Story.

Love Story (2016) is a video installation by South African-born and Berlin-based artist Candice Breitz, which I saw in the NGV Triennial at the National Gallery of Victoria in Melbourne in 2017. Via a large projection, Hollywood actors Alec Baldwin and Julianne Moore perform the stories of six refugees who had been interviewed by Candice Breitz in Berlin, Cape Town and New York. In the next room, the visitor can sit at eye-level with the refugees, who appear on six flatscreen monitors, and listen through headphones to their interviews, each of which lasted three to four hours. Four of the six interviews are also available on Vimeo ${ }^{2}$.

For the opening in Melbourne, Breitz renamed her work Wilson Must Go in protest of the gallery's use of Wilson Security's services ${ }^{3}$. All publicity material related to the work had to use the new name until the gallery dropped its security provider, Breitz decided. In February 2018, two months after the Triennial was opened, NGV selected a new security company. Wilson Security had provided guards for Australia's offshore detention centres on Nauru (since 2012) and on Manus Island (from 2014 until October 2017), and its staff had been accused of or been implicated in human rights violations, as was reported in The Guardian's Nauru files (Evershed et al, 2016). Candice Breitz (2017a) therefore felt that "it would be morally remiss, in light of the above knowledge, for me to remain silent in the context of the current

\footnotetext{
${ }^{2}$ https://vimeo.com/candicebreitz/. The two interviews are not online because the people interviewed in them are still going through an asylum process. Breitz (2018) asked each interviewee to decide if they wished their interview to be available online or not.

${ }^{3}$ See Neumann \& Horsti, 2017.
} 
conversation that is taking place around the Australian government's ongoing and systematic abuse of refugees." The local Artists' Committee in Melbourne had already protested NGV's security contract before the Triennial, but the gallery had not responded seriously. The Committee had then contacted the international artists participating in the Triennial, hoping that the status of these artists would force the gallery to address the ethical problem.

Sitting in front of an audience including NGV curators during the opening weekend event, Breitz (2017b) acknowledged the hierarchical relations at work in the protest: "I need to say that in terms of the protests this week, the Artists' Committee have done all the leg work. Of course it's very easy for a foreign artist to parachute in and have an immediate platform. I have an automatic level of visibility as a result of being an artist in this exhibition. I want to use that visibility to thematize what is going on at the NGV and to make it a little less likely that Wilson or a likeminded company will be selected when it comes to the permanent security contractor. The Artists' Committee has already staged compelling protests. They are the individuals who have the most to lose in this context. They have neither the prominence nor the security that I have. They have nevertheless insisted on conducting an ethical political dialogue with this very powerful institution."

The decision to rename the installation, Candice Breitz said, was made in solidarity with three different institutions or groups of people: with the gallery that had commissioned her work and that she believed was not going in the right ethical direction by contracting Wilson Security, with the Melbourne based Artists' Committee and with the refugees she had interviewed. It also threatened Breitz's 
artwork: "The same eyes that watched over murder, rape and child abuse in the detainment centres where refugees are held would be watching over my work, these same people would be providing care for my work. This scene became repulsive to me. I felt a responsibility not only to my practice, but also to the interviewees [who are featured in the artwork] and to this museum, which has been so generous to me." (Breitz 2017b.)

Breitz was simultaneously concerned about her own installation, the ethics of the gallery that had partly commissioned it and her responsibility to the refugees who had shared their testimonies. Breitz acted on the premise of rights-based solidarity, on a moral practice that aims to over come injustice (Laitinen, 2013). She chose to take a position that was compatible with the ethics of her work and with the political position that she shared with the refugees who she had interviewed. Therefore, her ethics of listening (Dreher 2009) to refugee experiences included the responsibility to care for the relationships she had with the refugees and to recognize her own privileged position as a well-known artist and the audible "voice" that came with it.

However, the protest was also a gesture toward the publics who might find the presence of Wilson Security an offence to their experience of the museum. Breitz's protest opened a critical position for the public to identify with so that they could continue to engage with art that immerses the viewer in the conditions of refugees. Moreover, the Triennial exhibition could go on to become a legitimate space for conversation about the treatment of refugees by the Australian government and in other contexts beyond Australia. The exhibition included several other works that engaged with the topic of refugees, and some of the artists followed Breitz in 
participating in the Wilson Security protest, while others did not (see more details in Neumann \& Horsti 2017).

The first room of Wilson Must Go the installation resembles a movie theatre: on a projection in a dark room, Hollywood actors Alec Baldwin and Julianne Moore reenact refugee narratives. The script is cut from transcripts of six testimonies in a fastpaced montage. The script that Baldwin and Moore perform is in first-person singular. The refugee tells his or her story to the artist, Candice Breitz. The artist as listener is explicit in the script in the form of address, such as "Candice, I didn't understand". But the script also reveals that the refugee is aware that his or her story will be remediated by Baldwin or Moore. The refugees address them, too, which is a discursive strategy that adds some humour and lightness to the viewing experience: "First of all, I want to thank Alex for being part of-Oh, Alec! The name is Alec."

The piece establishes a sense of reciprocity and mutual recognition between the refugees, the celebrities and the artist. First, the script reveals how both the refugees and the celebrities are actors in Candice Breitz's work. Secondly, the connection between the two groups of actors is mediated through objects. Each of the refugees has given Breitz a piece of jewellery or personal object that Moore and Baldwin then wore as they re-performed the relevant person's story. The object is a sign of the individual who is speaking through the voice of the Hollywood actor. For example, in the re-performance of José Maria João, an Angolan refugee in South Africa, Alec Baldwin wears José Maria João’s copper bangle and says: “I just want to tell Mr. Alec- when this guy Alec tells my story, he has to get it right. Mr. Alec, you must be happy that Candice is giving you this opportunity to give the people my story, to tell 
them about my life." As José Maria João sees it, Baldwin is privileged to be able to tell his story, and therefore, Baldwin holds a certain responsibility toward him.

Another refugee reflection is enacted by Julianne Moore: "I know when she [Julianne Moore] will listen to the story and share it with the world, I know it wouldn't be the same as if it was just me, coming to stand here, just me sharing my story, because I don't think that all those nice people would come and listen to my story." Here, the audience becomes the fourth agent in the installation - along with the Hollywood actors, the refugees and Candice Breitz. We in the audience are "all those nice people" who listen to the story, perhaps only because it is retold by a celebrity. The story is re-told in the sphere of the popular, and it is therefore consumable. We, the visitors, are offered the position of conditional listeners, tied to the economies of attention and affect.

Candice Breitz's motivation for the installation was to reveal the hierarchical positioning of stories, storytellers and listeners. Her website explains: "The work deploys the hypervisibility of Moore and Baldwin to amplify stories that might otherwise fail to elicit mainstream attention or empathy. At the same time, it reflects on the callousness of a media-saturated culture in which strong identification with fictional characters and celebrity figures runs parallel to a widespread lack of interest in people facing real-world adversity." In doing so, she moves to a metarepresentational level from arts-based participatory storytelling: practice that potentially creates critical space and acts of citizenship but that sometimes fails to profoundly contest exclusion, stereotyping and marginalization of refugees (Rovisco, 2015). 
The gallery visitor becomes aware of the sphere of the popular and the dynamics of representation and attention: Alec Baldwin and Julianne Moore capture our attention no matter what they say. The aesthetic of the movie theatre, the big screen, underline this. But importantly, when we do listen to what they say, that they tell the stories of refugees, we become alerted to the issue Breitz wants to underline: the experiences of suffering by real-life people.

The fast-paced montage interweaves lines from Baldwin that are cut to lines from Moore. This produces a kind of awkward dialogue where different parts of the world, different kinds of borders, different dangers and different reasons to flee are knitted together. Contrary to Timo Wright's sound installation, these stories do not blur into a singular refugee experience or one abstract "no-place", an un-contextualized border. Breitz identifies the refugees, who describe in detail the places and the borders they have crossed. Nevertheless, to keep up with the fast pace of the installation, I had to ignore the details and return to them afterward. There was no time to pause and ask: "where, why, which border, which conflict?" The focus of this part of the artwork emphasized the metarepresentational issues rather than the actual stories of refugees.

Only by passing through the space where Alec Baldwin and Julianne Moore re-enact the refugee stories, in their American English, on a green-screen set can the visitor enter the second space of the installation and sit across from the six television screens with headphones where the six refugees tell their stories - also on a green-screen set to Candice Breitz (who is off-screen but addressed in the stories). In this room, the viewer meets six very different contexts for fleeing. "My name is José Maria João. I 
am from Angola. I am born in the province, the village, of Damba. Damba is near Congo, 200 kilometres from Congo." João details how he managed to move in the borderlands between Namibia and Angola by pretending to be a mute man collecting wood and how he jumped over a metal fence between the countries. This detailed narrative paints an image of a specific borderland, which is different from, for example, the border crossing of another interviewee, Sarah Ezzat Mardini, who recalls how she jumped into the cold, dark Aegean Sea when the rubber dinghy's motor stopped running on the route from Turkey to Greece. She had been a competitive swimmer in Syria, so she swam and pulled the boatload of 17 people to safety.

The variety of the stories and of the places the interviewees fled from (Venezuela, Syria, Somalia, India, Angola and the Democratic Republic of Congo) produces potential for global solidarity, particularly so in the section where the visitor has time to listen to each of them. In the enacted section, the different narratives interconnect, and in the second room, the stories are told simultaneously side-by-side, creating a copresence of narration and a potential co-presence of the experience of fleeing. However, in Breitz's work, the multidirectionality of the experiences makes it impossible to think of any generalized, abstract refugee or refugee voice. The work expresses the multiplicity of being a refugee - there are narratives of persecution based on religion and sexual orientation as well as war - and in doing so, potentially allows the spectator to recognize the diversity of refugees: "anyone, even me, might have to flee", the visitor might think. Moreover, the location of the installation's first exhibition in Stuttgart, Germany, in 2016 powerfully elucidated how the arrival of refugees is a global issue, not a predominantly European one: at the time, Europeans 
were caught up in the situation on their own continent, the so-called "European refugee crisis". The installation reminds the viewer that there are places and reasons to flee that do not receive the same attention in the European media that refugees arriving in Europe do. The installation evokes solidarity across different border zones and disrupts the Eurocentric representation of fleeing.

\section{Conclusions}

Both The Long Journey Home and Love Story/(temporarily titled Wilson Must Go) produce multidirectional potential of solidarity by considering the references and connections to histories, identity positions, border zones, and experiences that might produce mutual understanding and invite reciprocity. In Wright's work, the actor and his steady emotional register amalgamates the memories of fleeing that happened in different time periods and at different borders into one narrative, possibly producing solidarity across different places and different temporalities. However, the work's position requires the viewer to identify with Karelian evacuees or with war children, which is more problematic than the installation and the surrounding historical exhibition admit. The kind of sociality that the museum presents as a foundation for solidarity is a sanitized and unified national community of Finns. Nevertheless, the installation also offers a critical position by inviting the viewer to include present-day refugees in the category of the national "we": the memories of fleeing from other places amalgamate into an equally important national memory of the forced displacements that took place at the Finnish border. 
In Candice Breitz's work, the actors also re-enact refugee testimonies, but the multivocality is more explicit than in Wright's work. The stories do not amalgamate into one; instead, their distinctiveness is highlighted in the second space of the installation. Breitz's work produces the potential for solidarity with refugees first by making the viewer think critically of the politics of attention and listening, the privileged positions of the celebrity, the artist, and the spectator, and then by inviting the visitor to sit at eye-level with the refugees and listen to the stories they perform. The co-presence of the stories connects various conflicts and borders and by doing that produces a potential for global solidarity.

Moreover, Candice Breitz's protest in Melbourne exemplified how ethical listening (Dreher 2012) in art that uses other people's stories, and more specifically, stories told by those in vulnerable positions, extends to the situatedness of the artwork. Breitz acted in solidarity with the refugees she had interviewed for the installation when taking a position of protest against the "eyes that watched over murder, rape and child abuse in the detainment centres" watching over not only her own work, but also over the stories of the refugees with whom she had created the artwork.

Finally, the artworks elucidate the metarepresentational level by using celebrity actors who perform the storytelling of refugees. Both installations successfully direct the viewer's attention to the politics of listening instead of focusing on the typical concern of "giving voice". This becomes explicit in the spheres of contemporary art and history museums. The popular actors attract the attention of the museum visitor. The popularity of the actors blurs the boundaries between genres and between the spheres of popular culture, contemporary "high" art and historical museums. The 
voice of the actor that re-enacts refugee narratives produces familiarity, or "audibility", for the horrific contents of the stories. Yet, at the same time the familiarity of the actor alerts the visitor to the politics of listening: "I am listening because I 'know' the one who tells". In Breitz's work this metarepresentational level is explicit.

The artworks therefore managed to produce the potential for ethical listening, which requires interrogation into the privileges of the listener. The celebrities produced a kind of sociality different from that of typical celebrity advocacy. Instead of being at the centre of attention, their celebrity presence drew critical attention to the politics of listening.

\section{References}

Andersin, M. (2017). Personal communication, 18 January 2017.

Belfiore, E. \& Bennett, O. (2008). The Social Impact of the Arts: An Intellectual History. Basingstoke: Palgrave.

Bickford, S. (1996) The Dissonance of Democracy: Listening, Conflict and

Citizenship. London: Cornell University Press.

Breeitz, C. (2018) Personal communication, 3 August 2018.

Breitz, C. (2017a). Why I'm sabotaging my own work. Wilson Must Go. Public statement, 12 December 2017.

Breitz, C. (2017b) Candice Breitz in conversation, National Gallery of Victoria, Melbourne, 17 December 2017.

Chouliaraki, L. (2012). The Theatricality of humanitarianism: A 
critique of celebrity advocacy, Communication and Critical/Cultural Studies, 9(1), 121,

Chouliaraki L. (2013). The Ironic Spectator: Solidarity in the Age of PostHumanitarianism. London: Polity Press.

Dreher, T. (2009) Listening across difference: Media and multiculturalism beyond the politics of voice, Continuum, 23(4), $445-458$.

Dreher, T. (2012). A partial promise of voice: digital storytelling and the limit of listening. Media International Australia Incorporating Culture and Policy: quarterly journal of media research and resources, 142, 157-166.

Driessens, O., Joye, S., \& Biltereyst, D. (2012). The X-factor of charity: A critical analysis of celebrities' involvement in the 2010 Flemish and Dutch Haiti relief shows. Media Culture Society, 34(6), 709-725.

Erll, A. (2011). “Travelling memory”, Parallax 71(4): 4-18.

Evershed, N., Liu, R., Farrell, P. \& Davidson, H. (2016). The Nauru files: The lives of asylum seekers in detention detailed in a unique database. Guardian, 10 August, 2016, available at:

https://www.theguardian.com/australia-news/ng-interactive/2016/aug/10/the-naurufiles-the-lives-of-asylum-seekers-in-detention-detailed-in-a-unique-databaseinteractive

Fassin D. (2012). Humanitarian Reason: A Moral History of the Present. Los Angeles: University of California Press.

Goodman, M., \& Barnes, C. (2011). Star/poverty space: The making of the “'development celebrity.', Celebrity Studies, 2(1), 69-85.

Horsti, K. (2013). De-ethnicized Victims: Mediatized Advocacy for Asylum Seekers, Journalism: Theory, Practice \& Criticism, 14(1): 78 - 95. 
Husband, C. (1996) The right to be understood: conceiving the multi-ethic public sphere, Innovation: The European Journal of Social Sciences, 9(2), 205 - 15.

Laitinen, A. (2013). Solidarity. In B. Kaldis (Ed.), Encyclopedia of Philosophy and the Social Sciences (pp. 948 - 950). London: Sage.

Laitinen, A. \& Pessi, A. B. (2015). Solidarity: Theory and Practice. Lanham: Lexington Books.

Landsber, A. (2004) Prosthetic Memory: The Transformation of American Remembrance in the Age of Mass Culture. New York: Columbia University Press. Musarò, P. (2017) The art of de-bordering: How the theatre of Cantieri Meticci challenges the lines between citizens and non-citizens. In L Iannelli \& P Musarò (eds.) Performative Citizenship Public Art, Urban Design, and Political Participation. Milan: Mimesis International, pp. 93 - 113.

Neumann, K. (2000). Shifting memories: The Nazi past in the new Germany, Ann Arbor: University of Michigan Press.

Neumann, K. (2016). New lives in a new country? National Library of Australia lecture series, 10 May 2016. https://www.nla.gov.au/audio/new-lives-in-a-new$\underline{\text { country }}$

Neumann, K. \& Horsti, K. (2017) It's hard to put a lid on the world. Inside Story, 20 December, 2017. Available at: http://insidestory.org.au/its-hard-to-put-a-lid-on-theworld/

Ong, J. C. (2014). "Witnessing" or "mediating" distant suffering? Ethical questions across moments of text, production and reception, Television \& New Media 15(3), 179-196.

Papastergiadis, N. (2010). Spatial Aesthetics, Art, Place, and the Everyday. Amsterdam: Institute of Network Cultures. 
Raninen-Siiskonen, T. (1999). Vieraana omalla maalla. Tutkimus karjalaisen siirtoväen muistelukerronnasta. Suomalaisen Kirjallisuuden Seuran Toimituksia 766. Helsinki: Suomalaisen Kirjallisuuden Seura.

Ratcliffe, K. (2005). Rhetorical Listening: Identification, Gender, Whiteness.

Carbondale: Southern Illinois University Press.

Rorty, R. (1989). Contingency, Irony, and Solidarity. Cambridge: Cambridge

Universtity Press.

Rothberg, M. (2009). Multidirectional memory: remembering the Holocaust in the age of decolonization, Stanford: Stanford University Press.

Rovisco, M. (2015). Community arts, new media and the desecuritisation of migration and asylum seeker issues in the UK. In Kinnvall, C. \& Svensson, T. (eds.) Governing Borders and Security: The politics of connectivity and dispersal, London: Routledge, pp. $99-116$.

Sallinen-Gimpl, P. (1994). Siirtokarjalainen identiteetti ja kulttuurien kohtaaminen. Kansatieteellinen arkisto 40. Helsinki: Suomen

Muinaismuistoyhdistys.

Scholtz, S. (2008). Political Solidarity. Philadelphia: Pennsylvania University Press.

Spivak, G.C. (1988.) Can the subaltern speak? In L. Nelson \& L. Grossberg (eds.) Marxism and the Interpretation of Culture (pp. 271 - 313). Chicago: University of Illinois Press.

Sreberny, A. (2006). 'Not Only, But Also’: Mixedness and Media. Journal of Ethnic and Migration Studies, 31(3), 443-459.

Ticktin, M. (2011). Casualties of Care: Immigration and the Politics of Humanitarianism in France, Berkeley: University of California Press. 
Wake, C. (2009).After effects: Performing the ends of memory. Performance Paradigm, 5(1), 5 - 11 .

Webb, J. (2009). Sentences from the archive. Performance Paradigm, 5(1), 66 - 81. Wright, T. (2018) Personal communication, 17 July 2018. 